\title{
Management of educational potential through extracurricular activities
}

Vladimir ENĂCHESCU ${ }^{1}$

\begin{abstract}
This article aims at studying the impact and role of extracurricular activities on the young and healthy formation and development of young people. The survey outlined the organizational arrangements, the steps teachers should take to ensure that extracurricular activities are successful and can achieve their original goal / goal, with the emphasis on learning. Reducing school dropout, reducing youth delinquency, reducing professional indecision, learning a job are some of the roles played by extracurricular activities; thus, education systems should encourage and support the realization of as many of these activities as possible. Also, various extracurricular activities from several countries / countries were nresented in the studv.
\end{abstract}

Keywords: extracurricular activities, young people, development, skills

JEL classification: I21, I23,I25

DOI: $10.24818 /$ RMCI.2019.3.317

\section{Introduction}

Extracurricular activities are defined as those activities that students attend after completing the usual daily courses according to Cadwallader, Garza and Wagner (2002). These activities may include school clubs, athletics team, school choir, school orchestra, leadership organizations for students, etc. It is very important to distinguish between extracurricular activities and co-curricular activities; according to Frame (2007), co-curricular activities are those activities that belong to normal class hours. Most students who belong to a school club spend countless hours off course lessons, which is why they are classified as extracurricular activities.

Extracurricular activities usually refer to those activities that complement the normal teaching-learning hours. The delimitation of such activities is difficult because these activities can be represented by excursions, visits to zoos, museums, theaters, public institutions, ballet, opera, visits to other schools, artistic activities, participation in environmental clean-up, participation in seminars / debates for professional orientation, thematic clubs, setting up a newspaper / radio station of the learning institution, etc.

\footnotetext{
${ }^{1}$ Vladimir Enăchescu, vld_enachescu@yahoo.com, Bucharest University of Economic Studies, Department of Teacher Training
} 


\section{Organization of extracurricular activities}

Like any work done for a well-defined purpose, extracurricular activity has a certain structure and form of organization that is ensured through the design, implementation and evaluation process. The success of these activities, which are not included in the normal curriculum, lies in the management of these three processes and the link between them. Since extracurricular activity has different characteristics depending on the extracurricular activity category concerned, the three processes undergo small changes depending on the specificity of the activity; instead, there are some general milestones for each process, which can be used in any extracurricular activity. The process of designing extracurricular activities takes place in several stages; according to Wheeler D.K. (1967), designing is a pentaphasic process that pursues the following aspects:

- Defining the purpose / scope of extracurricular activity

- Establish the extra-curricular experience that will achieve the goal. Stage where organizing and prior planning is required.

- Choosing the content that facilitates the learning process.

- Planning, organizing and integrating experience and content

- Assessment of extracurricular activity efficiency. The realization of an extracurricular activity involves the particularization of the activities to be pursued to the type and specificity of each category of activity, but also according to the collective from which the target group is formed.

Ensuring the quality and efficiency of extracurricular activity is achievable by applying principles of design and implementation, namely the principles presented by Santini in his theses:

- Focus on what is being learned

- Prohibited simplification - activity should be focused on student development

- Exhaustive solution - the requirements of all participants must be satisfied

- Total Transparency

- Complete information

- Clearly specified skills

- Part of the whole design process is only one stage of extracurricular activity

- Fidelity and efficiency - all information should be dealt with in the design and implementation of extracurricular activities.

- Full justification - objectives must be fully justified

- Early Valuation - Time Valuation of the Goal Review

- Complete collaboration - extra-curricular activity involves the collaboration of the teaching staff - the other members involved

- Full planning 


\section{Impact of extracurricular activities}

According to Reeves (2008), there is a close link between student involvement in extracurricular activities and improved attention, behavior and academic performance. In 2008, Reeves explained that all pupils participating in a type of extracurricular activity had better performance than students who did not engage in any activity. Whitley (1998) reported that participation in extracurricular activities may have a positive impact on students. It has been shown that participation in extracurricular activities has a wide range of benefits to students' performance and knowledge. By participating in these activities, students learn valuable hidden skills in extracurricular activities. Students learn to work in team, dedicate, time management, learn the ability to build positive relationships with other students, teachers, coaches or other members of the community. These acquired qualities can be used throughout students' efforts and achievements.

A study conducted in Lebanon, Beirut, aims to measure the level of stress and illness / psychological suffering among medical students and to study the link between involvement in extracurricular activities and diminishing stress levels and relieving the feeling of suffering experienced by them. The study was conducted on a sample of 165 randomly selected students; following their assessment, the results show that $62 \%$ of participating students have a high level of stress and $75 \%$ of them suffer. Extracurricular activities introduced in the article were: physical exercise, music, reading, and social activities. Thus, after an econometric analysis, the authors of the study concluded that students listening to music were correlated with a low level of suffering, social activities and housing with parents are associated with a low level of academic performance (Denault, Ratelle, Duchesne, Guay, 2019). In South Korea, an article was designed to analyze the impact of extracurricular activities on juvenile delinquency behavior. The study is based on a sample of 1,943 students of the 12th grade.

The conclusion of this 2017 study was that there is an inverse relationship between youth participation in extracurricular activities and their delinquent behavior; which means that young people participating in extracurricular activities are less exposed to committing crimes. Another article aims to analyze the impact of participation in extracurricular activities on the vocational development of pupils during high school. The study is based on a sample of 312 students who have been questioned over the course of three consecutive years about participation in extracurricular activities (both their number and type / category), vocational exploration and determination / indecision about the future career. The results of the study show that participation in a larger number of extracurricular activities is correlated with a more extensive exploration of the vocational fields in the following year of extracurricular activities, and the knowledge of these fields led to the decrease of the career indecision in the next year. Analyzing extracurricular activities (sports, artistic, social, cultural, academic, volunteer activities and civic activities), the study shows that participation in artistic and social-cultural activities leads to an increased willingness of students to explore professional areas, and participation in academic clubs, volunteering and civic activities lead to a decrease in career 
indecision until the end of the high school cycle. These results suggest that extracurricular activities could be promoted by career counselors as an additional strategy to help students explore the labor market.

Extracurricular activities in different countries / countries. According to Feldman and Matjasko (2005), such activities are followed by effects such as: increasing pupils 'performance and achievement, dropping out of school, improving pupils' psychological state (increasing self-confidence, reducing the feeling of loneliness / isolation group, diminishing worries about the professional future, etc.), decreasing the number of delinquent and anti-social behaviors, decreasing alcohol and drug abuse, etc.

Students who are constantly attending music clubs have better academic performance than students who do not participate in such activities (Cash, 2009). Cash (2009) states that most states do not have academic requirements for attending student clubs, participating in a band, participating in the choir or the orchestra of the institution; Instead, academic clubs, such as the National Honor Society, Key Club or Beta Club, have academic requirements. In some countries, the fanfare may have the same participation criteria as the criteria to be met by athletes for participating in competitions. In addition, states and school districts have set requirements for participation in school athletics based on grades, attention during school hours and behavior. Georgia has created "Georgia High School Association"; association that regulates athletics for the whole state; this association was established in 2010. The association sets out the categories of sports offered, the recognition of state champions and the eligibility requirements of a student for the competition.

In Romanian education, extracurricular activities have a rich tradition, although they are part of the mandatory curriculum in 2011, by introducing the new National Education Act. Thus, by introducing these legislative regulations, the Romanian education does not focus only on performance, but emphasis is on the practical skills, the development of certain qualities in accordance with the requirements on the labor market, the development of the personality of the young people.

In Romania there is "Such a Week"; a program dedicated to extracurricular and extracurricular activities. Under this program, students take part in extracurricular activities during one-week course hours; the number of hours of these activities being equal to the number of hours spent in a regular school week. Planning for these activities rests either with the teacher or with the management of the institution that can plan a few activities involving the entire college of the institution.

In many cities in Romania there is the Children's Palace or the Children's Club; this provides family and school with activities and facilities for enrolling children, helping them to develop and develop skills, character modeling, imagination and creativity, and in some of these institutions there are staff that can help participants draw a direction of professional achievement. Within these clubs, children have the opportunity to deepen the knowledge / notions acquired in educational institutions, to complete and apply practically. Many of the activities 
carried out in these youth programs are completed with participation in municipal, county and national competitions, helping talented children and workers to be known and to be able to claim on a larger scale.

There are a variety of nationalities in Germany, and for their integration, educational institutions carry out many extracurricular activities: linguistic, academic, sports, performance groups, etc. These activities promote the building of friendship relationships between people belonging to cultures, different religions and allow students to learn, improve and discover their talents and abilities outside of the classroom.

In France, a school day is long, and students and students spend a lot of time behind the bank where they read, write and listen to lessons taught. Thus, the time for extracurricular activities during a typical school day is low. However, French students and students have half a day or one free day in the middle of the week plus a weekend break for participating in such activities. Most municipalities in France offer a wide range of activities for children on Wednesdays, Weekends and school holidays. Extra-curricular activities that French students can attend include: swimming courses, cooking classes, yoga, scuba diving, musical clubs, sports clubs and theater clubs.

\section{DeMolay International}

DeMolay International is an international fraternal organization for young men aged 12-21, founded in Kansas, Missouri in 1919. The name of this organization is named after the last Grand Master of the Knights Templar, Jacques de Molay.

DeMolay is the first international youth leadership organization to shape leadership with character. Using timeless values and accepting the challenge of being a leader - both in character and in terms of action - young people in the fraternity turn into the highest ranking citizens. Each young person has his own experience within the organization: from generation of ideas, event planning, logistics coordination and plan execution, each of these stages being done to define their success. All this is done under the guidance of trained consultants selected from the local community, allowing each stage to be tailored in a unique way to support the interests of its members (Craft, 2012).

This brotherhood is an organization that asks its members to believe in a superior human being; they also believe that a high level of involvement and enthusiasm is more important to DeMolay's success than any particular ability and skill. In DeMolay, seven cardinal virtues are taught as ideals, such as:

- The love affiliate (love of parents)

- Respect for sacred things

- Courtesy

- Camaraderie

- Fidelity

- Cleaning / Purity

- Patriotism 
DeMolay events are different and different what other activities and events organized by someone else; these include sports tournaments, festive dinners, visits to children's hospitals, bargains and more. On the official site of the organisation it says: "If you can dream, you can do it in DeMolay." (If you can dream, you can do it at DeMolay). Young people are challenged to adopt new ideas and reflect on the creative approaches proposed by founders, service projects and fun events. Every year, activities change and change based on past results. Some events remain very special moments in young people's lives; young people enjoy within this organization experiences and challenges that they would not have tried.

\section{Conclusions}

Athletics, clubs and other extracurricular activities have advantages beyond the joy they offer to the participants. These activities help students develop personally, socially and intellectually; these activities also help students develop their academic and professional goals. Today, the number and type of extracurricular activities available are sometimes overwhelming. Students should choose activities that satisfy their interests and then weigh their activities to give them time so that extracurricular activities do not conflict with academic interests. Whether they are trying to improve their skills or improve their outlook, students have to go out for extra-curricular activity for at least one reason: have fun.

\section{References}

1. Craft S.W. - „The impact of extracurricular activities on student achievement at the high school level", The university of Southern Mississippi, The Aquila Digital Community, Spring-5, 2012

2. Denault A.S., Ratelle F.C., Duchesne S., Guay F. - „Extracurricular activities and career indecision: A look at the mediating role of vocation exploration", Journal of Vocation Behavior, Volume 110, Part A, February 2019, 43-53

3. Fares F., Saadeddin Z., Aridi H. et al -,, Extracurricular activities associated with stress and burnout in preclinical medical students", Journal of Epidemiology and Global Health (2016) 6, 177-185

4. Han S., Lee J, Park K.G - , The impact of extracurricular activities participation on youth delinquent behaviors: An intrumental variables approach", Journal of Adolescence, Volume 58, July 2017, 84-95

5. Ionescu D., Popescu R. - „Activități extrașcolare în ruralul românesc. Dezvoltarea de competențe cheie la copii și tineri ”, Fundația Soros. - București : Editura Universitară, 2011

6. DeMolay International, Lawhorn B. -,Extracurricular activities”, Occupational Outlook Quartely, Winter 2008-09

7. https://demolay.org

8. https://en.wikipedia.org/wiki/DeMolay_International 